doi: $\underline{10.29285 / a c t a p i n t e r i a n a .2021 .7 .5}$

\title{
Assisi Szent Ferenc karizmatikus pedagógiája ${ }^{1}$
}

\author{
Johannes-Baptist Freyer OFM \\ Missionszentrale der Franziskaner e. V., D-53177 Bonn, Albertus-Magnus-Str. 39. \\ johannes@mzf.org
}

Freyer, J.-B. (2021): Assisi Szent Ferenc karizmatikus pedagógiája. The charismatic pedagogy of Saint Francis of Assisi. Acta Pintériana, 7: 5-12.

\begin{abstract}
Saint Francis of Assisi was often described by his biographers as well as the authors of classical literature as „Father and Master”. He left a unique pedagogical approach to us, which did not resemble any method of external education that was in accordance with different rules of behaviour, but through this formation Francis formed the man in his whole being. According to the testimony of the Franciscan sources these key elements can be described as a formative process, which aims to reach acting with simplicity, orientation towards an objective, proceeding in a fraternal spirit, the experience of the word of God, provoking life according to the Gospel, also the authentic representation and unfolding of this new life. At the same time, Francis himself becomes a model and example on the way of formation, inspired by the Holy Spirit. The formation lived by Francis and his first Friars was the path towards real, evangelical and integral humanism.
\end{abstract}

\section{Formatív elemek Szent Ferenc életművében}

\begin{abstract}
„Boldogságos Ferenc atyánk tehát napról napra jobban eltelt a Szentlélek vigasztalásával és kegyelmével, és egy pillanatra sem szünt meg szorgoskodva és teljes odaadással újjáformálni új fiainak lelkét: különösen arra tanitotta öket, hogy biztos léptekkel haladjanak a szent szegénység és a boldog egyszerüség ösvényén."
\end{abstract}

(CÉ1 26)

Celanói Tamás és a szent más életrajzírói gyakran mutatták be Ferencet úgy, mint testvéreinek sajátos pedagógiai képességekkel megáldott mesterét és nevelöjét. Dante az Isteni szinjátékban szintén atyának és mesternek nevezi Ferencet (vö. Paradicsom, XI. ének). Celanói Tamás a fent idézett szövegrészletben körülírja Ferenc néhány nevelési elvét, amelyek iránt különös figyelemmel kell lennünk. Azt állítja, hogy Ferenc teljes odaadással igyekezett újjáformálni az első testvéreket: ez pedig elsősorban egy életforma, egy gondolkodás- és cselekvésmód, valamint egy elérendő cél átadását jelentette. Az első testvérek formálása nem hasonlítható semmiféle külső magatartási szabályok szerint kialakított pedagógiai módszerhez, de általa Ferenc az ember egész lényét formálta, s ezt nagy szeretettel és gondossággal tette. Mindehhez új alapelvekre tanította őket, ami arra ösztönözte a testvéreket, hogy egy

1 A fordítás az alábbi mű alapján készült, a szöveg angol változatának felhasználásával: J.-B. FREYER (2003): Francesco formatore di una vita nuova. In: „, Vestigia Christi hodie sequentes”. Acta Congressus Internationalis Secretariorum Pro Formatione et Studiis OFM, Assisi 13-27 Octobris 2002, Curia Generalis OFM Secretariatus pro Formatione et Studiis, Roma, pp. 129-138. 
kijelölt ösvényen, azaz egy formálódási folyamat útján járjanak. Ez a Ferencről alkotott kép lehetővé teszi számunkra, hogy úgy beszéljünk róla, mint a Pedagógusról - nagybetủvel.

Andrea Mercatali ferences szerzetes és a neveléstudomány kutatója mindemellett állítja:

„Szent Ferenc nem pedagógus, amennyiben a pedagógiát tudományos nézöpontból tekintjük, amely feltételezi a nevelés alapelveinek elméleti és gyakorlati rendszerezését. Mindazonáltal mégis pedagógiai tevékenységet végzett.” (MERCATALI 1982, p. 236; vö. SCHMUCKI 1985; TEMPERINI, p. 417; ZAVALLONI 1995, p. 76)

Ez a pedagógiai tevékenység abban nyilvánult meg, ahogy a testvér személyiségét gondolkodásának és cselekvésének átfogó egységében formálta. Tevékenysége a szeretet és a gondosság alapmagatartására épült, s új alapelvek alkalmazását hozta magával (vö. ZAVALLONI 1995, p. 27). Celanói Tamás nem fejti ki világosan, melyek ezek az új alapelvek. Tanulmányunk célja épp ezen új irányelvek körülírása, kifejezésre juttatása. Ezért szeretnénk felvázolni Ferenc új alapelveit a ferences források tanúsága alapján, anélkül, hogy azt állítanánk, ezzel ki tudjuk meríteni azt a gazdagságot, amelyet ez a terület kínál. Véleményem szerint a ferences források figyelmes olvasása Szent Ferenc alábbi hat nevelési elvét tárja elénk.

\section{A cselekvés egyszerüsége}

„Nem szabad bölcsnek és okosnak lennünk test szerint, hanem inkább egyszerünek, alázatosnak és tisztának kell lennünk." (2LHív 45)

Ferenc saját életének és kora eseményeinek értelmezési kulcsát a tiszta és szent egyszerüségben találta meg (vö. FREYER 2005b). Voltaképpen az egyszerüség volt cselekvésének alapja. Az egyszerüség segít megkülönböztetni a világ bölcsességét a valódi bölcsességtöl, amely Jézus Krisztus önkiüresítésében nyilvánult meg számunkra. Az egyszerüség, amely összezavarja a világ okosságát, életünket a valódi bölcsesség felé vezeti, amely a szegény és alázatos Krisztusban mutatkozott meg. Ferenc a megtestesült Krisztusban mint az igazi bölcsességben találta meg élete útját, s egész életét, annak minden eseményét és az öt körülvevő valóságot egyaránt a Jézus Krisztusban kinyilatkoztatott, mindent átfogó megváltás távlatába helyezte a cselekvés egyszerüsége által. Ily módon az egyszerüség, amelyet minden cselekedete igazodási pontjává tett, segíti az Úr Lelke szerint való életet. Ferenc számára a szív egyszerüsége a mindennapi élet, valamint az imádság és a szemlélődés megalapozásának legfőbb jellemzőjévé vált. Az élet konkrét eseményeit és Istennek az evangéliumokban feltáruló igéjét egyaránt az egyszerüség fényében értelmezte. Ugyanez az egyszerüség arra is szolgált, hogy Ferenc úrrá legyen azon a távolságon, amely a hétköznapi élet valósága és az Isten igéje által támasztott kihívások között feszült: így a való élet és a hit harmonikus és hiteles módon egyesült. Ez az egyszerüségben végzett cselekvés segítette Ferencet, hogy kritikus távolságot vegyen a világ önközpontúságával és antropocentrizmusával szemben, hogy felfedezze a megváltás misztériumát a megtestesült, szegény és alázatos Krisztusban, hogy harmonikus és hiteles módon tudja egyesíteni a hétköznapokat a hitben megélt élettel és hogy saját élettervét az Úr Lelke szerint építse fel.

Az egyszerüség - mint a képzés eleme és alapelve - magában foglalja:

- A testvér személyiségének karakterét - mesterkéletlen, mentes a bonyodalmaktól és a szeszélyektöl;

- A testvér életstílusát - szegénységben és egyszerüségben él; életstílusa nem rugaszkodik el a ‘humus’-tól, az élet valóságától; 
- A testvér Istenhez füződő kapcsolatát - egyesíti magában a Jézus Krisztusban kinyilatkoztatott megváltás ökonómiáját azáltal, hogy az Úr Lelke és szent munkálkodása szellemében él.

\section{Cél felé irányulás}

„Minden testvér igyekezzék követni a mi Urunk Jézus Krisztus alázatosságát és szegénységét, és emlékezzen arra, hogy nekünk az egész világból semmit nem szükséges birtokolnunk, csak úgy, amint az Apostol mondja: Ha van eledelünk és ruházatunk, elégedjünk meg velük. És örülniük kell, amikor alacsonysorsúak és megvetettek, szegények és félkegyelmüek, betegek, leprások és útszéli kéregetök közt forgolódnak. És ha a szükség úgy hozza, menjenek alamizsnát gyüjteni."

$(\mathrm{RnB} 9,1-3)$

Egyszerüségében Ferenc lassanként felfedezte élete célját: Jézus Krisztus nyomdokaiban járni. A megtestesült Krisztus, akit az Evangéliumban fedezett fel, figyelmének középpontjába került. Jézus Krisztus, akiben maga Isten nyilatkoztatja ki önmagát (vö. FREYER 1999; 2005a), nem pusztán egy életideál (vö. MERCATALI 1982, p. 240), hanem kézzelfogható példa lett Ferenc számára. Az vált egyszerüségben járt útjának céljává, hogy a maga konkrétságában élje Jézus Krisztus Evangéliumát kora hétköznapi valóságában. Ebből a Krisztus általi Istenhez ragaszkodásából kiindulva Ferenc egy alakító erejü ideálra irányítja társainak figyelmét: találkozni Istennel Krisztusban az élet valóságában (vö. MERCATALI 1982, pp. 242, 248). Ferenc nevelési célja az volt, hogy a testvérek megtanulják élni a szegény és alázatos Jézus Krisztus Evangéliumát. Ez a nevelés az ember egész lényét magába foglalja a szó igazi értelmében. A testvérek arra kaptak meghívást, hogy emberi mivoltuk minden dimenziójában fejlesszék személyiségüket az evangéliumi értékek vonzásában (vö. BRÜMAN 1978, p. 100). Miközben Ferenc Jézus Krisztusra mint célra irányította a testvérek figyelmét, új spirituális-teológiai, új gyakorlati és új társadalmi dimenziót kínált fel számukra. Ami a spirituális-teológiai síkot illeti, Ferenc az Istenember, Jézus Krisztus személyét állította modellként eléjük. Ennek újdonsága abban állt, hogy az Istenembert az ő szegénységében és alázatosságában látta, vagyis a mély inkarnációjában, amely az emberben és a teremtett világban valósul meg. Ez a sajátos Jézus-kép nem marad meg egy pusztán jámbor és vallásos megközelítésnél: ez a spirituális-teológiai látásmód az élet gyakorlati szintjén ölt testet. A testvéreknek emlékezniük kellett arra, hogy semmit sem birtokolhatnak ebből a világból az eledelen és a ruhán kívül, és elégedjenek meg ezekkel (vö. RnB 9,1-2). Ez spirituális-teológiai látásmód a legvalóságosabban a testvérek életstílusában (modus vivendi) öltött testet. A szegénység, az alázatosság és az egyszerüség elérendő céllá vált, hogy a testvérek konkrét módon gyakorolják a tulajdonnélküliséget és felesleges birtoklástól való tartózkodást. A spirituális-teológiai cél beletestesülése a hétköznapi élet valóságába egyúttal egy új társadalmi dimenzióhoz is közel vezette a testvéreket. Örülniük kellett annak, ha alacsonysorsúak és megvetettek között kellett élniük (vö. RnB 9,3). A Ferenc által képviselt nevelési célkitüzés része volt egy új elhelyezkedés kora társadalmában, amely ennek következtében egy új társadalmi látásmódot is hozott magával. A testvérek formációján keresztül Ferenc egyrészt az evangéliumi tökéletességet kívánta elérni az egyetlen életmodell, Jézus Krisztus követésében, másrészt az emberi személy átfogó elörehaladását mind egyéni, mind közösségi téren (vö. TEMPERINI 1992, p. 438).

\section{A testvéri élet lelkülete}

„Egyik testvér a másik elött aggodalom nélkül tárja fel szükségletét, hogy az elöteremtse és megadja neki, amire szüksége van. Amennyire Isten kegyelme 
engedi, ki-ki úgy szeresse és táplálja testvérét, miként az anya szereti és táplálja fiát." (RnB 9,10-11)

Egyszerüségében Ferenc nem pusztán egy, az egyénre vonatkozó nevelési célkitüzést állít elénk, de életterve egyúttal az egyénnek a testvéri életbe való integrálódását is segíti, ez pedig az evangéliumi értékek megvalósítása felé vezet. Az egyén a felkínált értékeket a testvéri közösségben építi be az életébe és teszi személyessé (vö. TEMPERINI 1992, p. 422). Mindannyian értékes szereplők, akik kölcsönösen cselekszenek egy valóban evangéliumi élet megvalósításáért. A személy egyedisége iránti tisztelethez, szeretethez és gondossághoz hozzáadódik a csoport, a testvéri közösség iránti figyelem és engedelmesség (vö. MERCATALI 1982, p. 243). Ferenc nevelésről alkotott elképzelésében remek egyensúlyban van az egyén és szükségletei, vágyai és álmai számára biztosított tér és a szabad integrálódás a testvéri közösségbe, annak szükségleteibe, értékeibe és életmodelljeibe. Betagozódásról és ráhagyatkozásról van tehát itt szó, a testvériségnek szóló mély elköteleződésről, amit ugyanakkor testvéri-anyai szeretettel kell viszonozni, nagy figyelemmel kísérve az adott testvért. Ennek a célnak eléréséhez elengedhetetlen a „táplálás”, mint a testvér, az embertársak és a teremtett világ iránti nagymértékü és valós empátia kifejeződése (vö. BRÜMAN 1978, p. 91; MERCATALI 1982, p. 244; TEMPERINI 1992, p. 423). E testvéri élet egyetlen célkitüzése az, hogy a különféle körülményeknek megfelelően tettekre váltsa az Evangélium lelkületét. A testvéri közösség ezért az evangelizáció és az Evangélium hirdetésének helyévé válik a világban $-\mathrm{s}$ ez egyszersmind missziós küldetése is. A nevelés - például a regulának való engedelmesség által - az életben, a munkában, a küldetésben, magában a hivatásban való osztozást mint az „evangéliumi projekt” kifejeződését akarja elősegíteni. A testvéri közösséghez való alkalmazkodás azt jelenti, hogy készek vagyunk együtt élni az azonos hivatást kapott emberekkel az Evangélium lelkületében, a való világban.

\section{Isten igéjének megtapasztalása}

„Mikor azonban egy napon mise közben hallotta, hogy miket mondott Krisztus tanítványainak, midön prédikálni küldte öket - hogy tudniillik ne legyen se aranyuk, se ezüstjük, se táskájuk, se erszényük, az útra ne vigyenek botot, és ne viseljenek se sarut, se köntöst-, és amikor a pap hozzáfüzött szavaiból még világosabban megértett mindent, kimondhatatlan örömre gyulladva igy kiáltott fel: "Igen, ez az, amit én teljes szívemböl tenni kívánok.»

Amit hallott, mindent szorgosan emlékezetébe vésett, s azontúl nagy lelki vigassággal azon igyekezett, hogy azt betü szerint megtegye. Elöször is túladott mindenen, amiböl egynél többje volt, azután eldobta magától a botot, sarut és erszényt, és végül egy ócska és durva csuhát tákolt össze magának, és azt bőröv helyett kötéllel vette körül. Ezenfelül szivének minden gondját és szorgoskodását kizárólag arra forditotta, hogy az új kijelentés szavait a töle telhetö módon végrehajtsa. Ezért az isteni kegyelem ösztönzésére serényen hirdetni kezdte az evangéliumi tökéletességet, egyszerü szavakkal a bünbánatról prédikált."

(3Társ 25)

Ferenc életformája és a hozzá való hasonulás megkívánja az elmélettől a gyakorlat felé való elmozdulást (vö. ZAVALLONI 1995, p. 79). Ferenc és az első társak útjának kezdeténél az a szándék állt, hogy Isten igéjét a gyakorlatba, a valóságba ültessék át; elkezdjék komolyan venni az Evangéliumot, és annak megértésével összhangban éljenek anélkül, hogy döntésük nyomán bármiféle biztosítékot keresnének. Minden lehetséges bizonytalanság ellenére, amit életmódjuk hordozott, Ferenc és követöi nagy bizalommal voltak Isten szava iránt. Engedték, hogy az Evangélium vezesse öket a mindennapok apró és nagy eseményeiben egyaránt. Így lehetőséget adtak Isten igéjének, hogy testükön, 
gondolataikon, munkájukon, prédikációjukon keresztül cselekedjen. „Próbára tenni Isten igéjét” azt jelentette, hogy úgy alakították életüket, hogy megtapasztalhassák, mi történik, ha egyszerüen az Evangélium értékeihez igazítják azt. Ez a fajta tapasztalat Isten szavának feltételek nélkül hallgatására hív, és megkívánja, hogy az egyén engedje, hogy maga Jézus Krisztus tanítsa őt a vele való találkozások közvetlenségében, ami az Igében, az Egyházban, a teremtésben, a szegényekkel és a peremre szorulókkal való találkozásban valósul meg. Ferenc ehhez a Jézus Krisztussal való közvetlen találkozáshoz akarta elvezetni a testvéreket. Ezért arra hívta őket - az egyes testvéreket és a közösséget egyaránt -, hogy legyenek nyitottak a világ, az emberek, az Egyház és - akkortájt különösképpen - a leprások iránt. Minden találkozás, amelybe az ember nagy nyitottsággal és empátiával engedi bele magát, Istennel való találkozássá, jelenlétének megtapasztalásává válik. Az Evangélium teljes erővel és lelkesedéssel való tettekre váltása és „kipróbálása” a valóságban egyszersmind a teljes ember formálódásává is válik, és képessé teszi arra, hogy haladjon az Isten felé vezető úton, megosztva testvérei örömét és szenvedését, segítve a szegényeket és a peremre szorulókat, támogatva az igazság szeretetét és a béke ajándékát (vö. ZAVALLONI 1995, p. 24).

\section{Felhívás az Evangélium szerinti életre}

„Szent Ferenc egy alkalommal meglátogatta az ostiai urat [...]. Midön elérkezett az étkezés ideje, óvatosan kilopakodott és ajtóról-ajtóra járva alamizsnát kéregetett. De mire visszatért, az ostiai urat számos lovaggal és nemessel egyetemben már asztalnál ülve találta. Ö is belépett tehát, a kapott alamizsnadarabokat odatette a biboros elé az asztalra s azután maga is helyet foglalt a bíboros oldalán [...]. A bíboros egy kicsit röstellte, hogy vendége alamizsna után járt és hogy a kapott darabokat az asztalra tette [...]. Szent Ferenc pedig, miután evett néhány falatot, fogta az alamizsnát $s$ az Úristen nevében minden lovagnak és a bíboros úr minden káplánjának adott belöle egyegy darabkát. [...]

A lakoma végeztével a bíboros visszavonult szobájába, de magával vitte szent Ferencet is. [...] azután így szólt hozzá:

„Óh együgyü testvérkém, miért szégyenitettél meg ma ennyire, hogy bár házamban szálltál meg, mely egyben testvéreid háza is és mégis kimentél alamizsnát koldulni? « Szent Ferenc azonban így válaszolt:

»Söt ellenkezöleg, uram, a legnagyobb tiszteletet tanúsítottam irántad. Mert amikor a szolga megteszi kötelességét és teljesíti ura akaratát, akkor tiszteletet tanúsit ura iránt«.

Majd igy folytatta tovább: „Nekem mintaképül kell szolgálnom az én szegényeimnek; föleg mivel tudom, hogy rendünkben vannak és lesznek testvérek, akik nemcsak nevük, hanem életük szerint is kisebb testvérek, $s$ akik az Úristen iránti szeretetböl és a Szentlélek kegyelméböl, aki megtanitja öket mindenre, készek magokat mindenben megalázni, akaratukat mások akaratához igazítani és testvéreiknek szolgálatára lenni. De viszont vannak és lesznek közöttük olyanok is, akik álszeméremböl vagy rossz szokásból vonakodnak és vonakodni fognak magukat megalázni és alamizsna után járni és más alsóbbrendü munkákat végezni. Nekem tehát kötelességem, hogy minden most élö és ezután jövendö testvéremnek példát adjak."” (TT 23)

Ez és számos más szövegrészlet is bemutatja számunkra, hogyan vált Ferenc az Evangélium sajátos megtapasztalása nyomán valóságos provokációvá környezete számára. Annyira mély meggyőződéssel 
tette belsővé az Evangélium értékeit, hogy mintának és példaképnek (vö. PL 2 - a ford.) nevezte magát, akit Isten szeretete sürget és a Szentlélek inspirál, hogy tettei és egész magatartása által másoknak is átadja az evangéliumi értékeket. Magatartása bizonyos értelemben valódi és hatásos provokációvá vált. Ferenc azt az életet akarta provokálni másokban, amely az általa is tapasztalt és megélt értékek mentén épül fel. Cselekedetei erős ösztönzést jelentettek mások számára abban, hogy ők is ragaszkodjanak életükkel az Evangéliumhoz. Ferenc nyomatékosan kérte a másik embert - legyen akár testvér, akár egy egyszerü, szegény ember, bíboros vagy pápa -, hogy létét fordítsa olyan irányba, amely a Krisztushoz való hasonulás által a teljes érettség ígéretét hordozza (vö. MERCATALI 1982, p. 239). Ferenc a maga formatív viselkedésével provokálta (előhívta) és ösztönözte a másik emberben mindazt, ami jó és szép, hogy így a másik átformálódjon a Krisztusban való teljes emberi érettségre. Ezen a ponton az Evangéliumhoz kapcsolódó formálódás összetalálkozik az emberi fejlődéssel. Ferenc nemcsak önmagára tekintett úgy mint modellre, amely arra hivatott, hogy elsőként önmagában, majd testvéreiben is felébressze az evangéliumi értékeket. Azt akarta, hogy ilyen módon testvérei is az evangéliumi élet igazi felszítói legyenek ebben a világban. Csakúgy, mint Ferencnél, az efféle provokáció szolgálata nagy szabadságot igényel: szabadságot önmagunktól és szabadságot a dolgok birtoklásától. Ezen a ponton a szegénység siet segítségünkre és egyesül a szabadsággal, amely az evangéliumi értékek terjesztésének szabadsága, szabadság arra, hogy tanúságot tegyünk az igazságról és az evangéliumi életről (vö. FREYER 2001, p. 380). Ferenc erre a szabadságra akarta formálni önmagát és testvéreit: szabadnak lenni, hogy képesek legyenek felkelteni az evangéliumhoz való ragaszkodás vágyát akár azokban, akik az emberek szemében jelentéktelennek tüntek, akár azokban, akiket nagynak és erősnek tartottak. Regulájával, minden előírásával és intelmével arra próbálta tanítani a testvéreket, hogy élő legyen bennük az érzékenység az evangéliumi szabadságra (vö. BRÜMAN 1978, p. 96; ZAVALLONI 1995, p. 79), a szabadságra, amely Isten nevében pozitív provokációvá alakul.

\section{Az új élet ábrázolása}

„A szent atya, mikor egyszer San Damianóban idözött, helyettesének ismételt sürgetésére, hogy lányainak hirdesse az Isten igéjét, végre beleegyezését adta.

Mikor a növérek szokás szerint összegyültek, hogy hallgassák Isten igéjét, de még inkább azért, hogy lássák atyjukat, ö az égre emelte tekintetét, ahol szivét mindig tartotta, és imádkozni kezdett Krisztushoz. Utána hamut kért; ebböl kört vont maga köré a padlón, a megmaradt részt pedig fejére hintette.

A növérek várakozással tekintettek a boldogságos atyára, aki a körön belül mély csendbe temetkezett; szívük nem kis csodálkozással telt el. A szent egyszerre csak felállott, és nagy elképedésükre beszéd helyett a Miserere zsoltárra gyújtott rá. Ennek végeztével gyorsan kiment a templomból.

E néma prédikáció hatása alatt Isten szolgálói olyan mélységes bánattal teltek el, hogy szemükböl valóságos könnypatakok ömlöttek. " (CÉ2 207)

Ferenc életének és tevékenységének középpontjában az a hivatás állt, hogy szavaival és tetteivel tanúságot tegyen az Evangéliumról. Ez a tanúságtétel gyakran egész különleges módon, élénk, gazdag jelentést hordozó formában és ábrázolások útján valósult meg (vö. BRÜMAN 1978, p. 92). Ferencben mélységesen eleven az udvari bolond és a trubadúr karaktere. Egész érzelemteli, képzeletgazdag, kreatív természetét bevonta tanúságtételébe (vö. MERCATALI 1982, p. 250). Viselkedése látványossággá vált, amely nagy meghökkenést váltott ki a szemlélők lelkében. Azzal, hogy ilyen módon cselekedett, Ferenc sokkal többet fejezett ki annál, mint ami szavakkal átadható. Egy mondanivalóban gazdag jelenetben ábrázolja Krisztus igaz tanítványának új életét. A Jó Hír ábrázolásának és bemutatásának ez a szentferenci módja valódi és alkalmas nevelési módszernek bizonyult, mert a befogadókat létük 
legmélyén érintette meg. Viselkedésmódja megütköztető, reflektálásra késztet, és arra ösztönöz, hogy nyíltan állást foglaljunk vele és az általa átadott üzenettel kapcsolatban. Ferenc ily módon minden szemlélőt bevont annak érdekében, hogy senki se maradjon pusztán megfigyelő, hanem valamiképpen mindenki résztvevővé váljon az új, Evangélium szerinti élet megjelenítésében. Így Ferenc személye élő és ösztönző képpé vált. Ferenc igehirdetésének célját nem valamely moralizáló vagy fenyegető beszéd révén érte el, még kevésbé ellentmondást nem türő parancsokkal vagy regulájának utasításaival, hanem sokkal inkább az emberek szívéig ható intuícióval, képzelőerővel, érzékenységgel, megértéssel és beleérzőképességgel. Ferenc sohasem játszott bohócot, de „Isten bolondjaként” viselkedett. Miután teljes léte Istentől származott, látható módon fejezte ki hitét, és megmutatta azokat az érzéseket, amelyeket Isten elött már hitelesnek talált. A hit kifejezésének ezt az őszinteségét és egyenességét egy festöi jelenetben foglalta újra össze és jelenítette meg. Ferenc nem vett magára semmiféle színpadias szerepet, ehelyett inkább önmagát és Istennel való kapcsolatát mutatta be. Ez a gyakorlati és hajszálpontos megjelenítés senkit sem hagyott közömbösen. Itt rejlik a tanítás és a nevelés valósága. Ferenc nevelte és alakította a látást és a hallást. Nevelés és formálás volt ez, a pedagógia minden tudományos vagy professzionális módszertana nélkül, ugyanakkor mégis mélységes hatékonysággal.

\section{Ferenc, a formáció mestere}

Ahogy azt a ferences források különböző szövegrészletei elénk tárják, Ferenc úgy jelenik meg előttünk, mint a formáció mestere. Személyisége az Evangéliummal való találkozásban jutott el a teljes érettségre (vö. STICCO 1926). Az Evangéliumban Krisztus úgy kínálja fel magát Ferenc számára mint egyetlen igazi Mester. Ferenc pedig egész lényével Krisztus életéhez akar hasonulni. Ferenc sohasem tekintett volna önmagára a nevelés mestereként. Benne azonban megláthatjuk, ahogy az egész élete a formálódás folyamatává vált az Istennel való konkrét találkozás által. A hétköznapi valóság szembesítése az Evangélium élő üzenetével mind újabb tapasztalatokra vezeti oot, ezek pedig abban segítik, hogy újabb és újabb lépéseket tegyen meg a teljes emberré válás útján, a megváltás távlata felé haladva. Ferenc vágyott arra, hogy megossza tapasztalatát másokkal, testvéreivel, nem többet és nem kevesebbet, mint az életében Istenről szerzett tapasztalatát. Ez a formálódási folyamat magán a megélt életen keresztül egyedülálló módon vezeti az embert az Istenben való önmegvalósítása felé. A Ferenc és első társai által megélt formáció ebben az értelemben a valódi, evangéliumi és teljes emberség felé vezető ösvény volt (vö. TEMPERINI 1992, p. 437).

Anélkül, hogy úgy tennénk, mintha sikerült volna kimerítenünk az itt tárgyalt témakört, szeretnénk összefoglalni a Szent Ferenc életén alapuló nevelési út alábbi jellemzöit:

1. Egyszerüen élni, cselekedni, gondolkodni és beszélni;

2. A teljes személyiséget a maga integritásával az egyetlen formatív ideál, az Istennel való találkozás felé irányítani az élet valóságában;

3. Ösztönözni a megfelelő egyensúly kialakítását az egyénre irányuló figyelem és a testvéri közösségbe való integráció között;

4. „Kipróbálni” Isten igéjét a maga valóságos megtestesülésével életünkben;

5. Felkelteni mindenkiben azt, ami jó és nemes annak érdekében, hogy öszinte szívvel élhesse az Evangéliumot;

6. Megjeleníteni és ábrázolni a Krisztusban való új életet létünk minden lehetséges dimenziójában.

Forditotta: Kámán Veronika (kaman.veronika@ferencesek.hu) 


\section{Irodalom - References}

BALANYI, GY. (szerk.) (1926): A tökéletesség tükre. Élet, Budapest. (ford. Balanyi Gy.) [TT]

BRÜHMANN, K. (1978): Anthropologische und Pädagogische Leitlinien in den Schriften des Heiligen Franziskus von Assisi. Wissenschaft und Weisheit, 41: 84-102.

FERENC, Assisi Szent (1995): A három társ legendája. Ferences Források 3., Agapé, Újvidék; Szeged \& Csíksomlyó. (ford. Balanyi Gy. \& Hidász F.; bev. Várnai J.)

FERENC, Assisi Szent (2018): Assisi Szent Ferenc irásai. Ferences Források Magyarul 3., Magyarok Nagyasszonya Ferences Rendtartomány, Budapest.

FERENC, Assisi Szent (1997): Assisi Szent Ferenc perugiai legendája. Ferences Források 5., Agapé, Szeged. [PL]

FREYER, J.-B. (2005a): „Das wahre Licht, unseren Herrn Jesus Christus sehen”. Die Christologie des heiligen Franziskus nach seinen Schriften. Archivum Franicanum Historicum, 98: 9-40.

FREYER, J.-B. (1999): „Gott, der Vater unsers Herrn Jesus Christus.” Die Vision Gottvaters bei Franziskus. Wissenschaft und Weisheit, 62: 276-291.

FREYER, J.-B. (2001): Homo Viator: Der Mensch im Lichte der Heilsgeschichte. Eine theologische Anthropologie aus franziskanischer Perspektive. Veröffentlichungen der Johannes-Duns-SkotusAkademie für Franziskanische Geistesgeschichte und Spiritualität, Mönchengladbach 13, Butzon \& Bercker, Kevelaer.

FREYER, J.-B. (2005b): „Ignorans sum et idiota.” Az egyszerüség mint a tudás és bölcsesség forrása Assisi Szent Ferencnél. Vigilia, 70: 772-783.

Mercatali, A. (1982): San Francesco 'Padre e Maestro.' Orientamenti Pedagogici di S. Francesco D’Assisi. Antonianum, 57: 230-258.

SCHMUCKI, O. (1985): Francesco maestro e guida dei suoi figli. L'Italia Francescana, 60: 423-426.

STICCO, M. (1926): L'originalità del pensiero di san Francesco nell'educazione. Fiamma Viva, 6: 627640.

TAMÁs, Celanói (1993): Celanói Tamás életrajzai Szent Ferencröl. Ferences Források 2., Agapé, Újvidék; Szeged \& Csíksomlyó. (ford. Balanyi Gy.; Hidász F. \& Várnai J.)

TEMPERINI, L. (1992): Francesco, Maestro di formazione. Analecta Tor, 22: 413-440.

Zavalloni, R. (1995): Pedagogia Francescana. Sviluppi e prospettive. Ed. Porziuncola, Assisi. 